\title{
Visionaries from the East as Guiding Principles for Western Education
}

\author{
Stephen R. White ${ }^{1}$, John Janowiak ${ }^{2}$ \\ ${ }^{1}$ Department of Leadership \& Educational Studies, Appalachian State University, Boone, USA \\ ${ }^{2}$ Department of Curriculum \& Instruction, Appalachian State University, Boone, USA \\ Email: whitesr@boone.net, janowiakjf@appstate.edu
}

Received October $30^{\text {th }}$, 2011; revised November $24^{\text {th }}$, 2011; accepted December $10^{\text {th }}, 2011$

\begin{abstract}
Our analysis of western education is not a "how to" prescription. It is a meaningful and reflective theoretical position as to "what is" the meaning of education, to us. Thus this work is a unique look at the collaboration as a constructive "process," theoretically an endeavor of reflection, over that of a detailed pragmatic narration of education. Therefore, we believe, it is in spirit of the act of collaboration as process of knowledge revelation. Given this our analysis does not address each and every question posed, specifically, but is a work that sheds light and illuminates the process of education and in doing so does cast a pragmatic shadow over all the questions of interest for this issue. In short, we believe that this work of ours is visionary in scope and relevance.
\end{abstract}

Keywords: Western Education; Eastern Principles; Sri Aurobindo; Paramahansa Yoganada

\section{Western Education}

The integral knowledge admits the valid truth of all views of existence, valid in their own field, but seeks to get rid of their limitations and negations and to harmonize and reconcile these partial truths in a larger truth... It is not by "thinking out" the entire reality, but by a change of consciousness that one can pass from the ignorance to the Knowledge-the Knowledge by which we can become what we know (Dalal, 2001: p. 3).

—Indian Philosopher, Sri Ghose Aurobindo (1872-1950)

\section{The Infusion of Spirituality into Education}

A major challenge for educators today is to construct visionary and novel ideas necessary to understand the complexity of evolving new personal and social realities. Educational philosopher James Moffett observed (1994).

Evolution seems to press forward with a will of its own that gives history a direction no government ever planned. We must now become conscious of this direction and try to interpret its import for the future society... The more we take evolution into our own hands, the less destructive it needs to be. By basing education on the past we fight evolution and force it to force us, through extremity (p. 15).

The integration of spirituality and metaphysics has become an issue of growing debate in the curriculum of higher education. This development illuminates what appears to be a shift back toward the exploration of spiritual concerns submerged since the advent of scientific positivisms and the effort to reduce, if not eradicate, the role of spirituality in education (Bertrand, 2003; Kessler, 2000; Moffett, 1994; Palmer, 1999). Many educational theorists believe that spirituality is a basic human inner drive, a cognitive energy having multiple forms of expression, with religion being only one. The thinking is that spiritually grounded learners are vibrant thinkers because the soul is harmonious with the mind. Therefore the educational process should focus on the development of the whole person to make mean- ingful intellectual connections between the social life-world "without" as well as their psyche soulful life-world "within." As such, educators are obligated to honor spirituality as part of learners' developmental process (Miller \& Nakagawa, 2002; Glazer, 1994; Sinetar, 2000).

Recently a group of theorists have espoused spirituality as being an integral part of postsecondary education. They proclaim that the history of Western postsecondary education reveals that the profession was originally deeply rooted in spiritual development. Their call is for a renewed reconciliation between spirituality and intellectuality. They believe that academics can accomplish this through consciously integrating spiritual elements into reflectively constructed educational programs and learning experiences. The challenge today for leadership in education is to recover its spiritual heritage and infuse it back into the learning process (English, Fenwick, \& Parsons, 2003).

The goal of education is to develop the objective rational intellect and to nurture the subjective domain of the mind. It is from the subjective intellect that a sense of wonder emerges that is integrated with the objective domain and rational inquiry. An adherence to subjective inner exploration of learners as part of their intellectual development constitutes learning as a spiritual journey, which is in essence the very soul of education (Palmer, 1993). Our belief is that this challenge can be partially addressed by looking to the East into the philosophies and teachings of Paramahansa Yogananda and Sri Aurobindo.

\section{A Vision from the East: Yogananda's Self-Realization}

"God is simple. Everything else is complex." -P. Yogananda

Paramahansa Yogananda (1893-1952) was born Mukunda Lal Ghosh in Gorakhpur, India, into an affluent Bengali family. From his earliest years, the depth of his awareness and experi- 
ence of spirituality was noteworthy. In his youth, he sought out many of India's sages and saints, in search of an illumined teacher to guide him in his spiritual quest, which he later recounted in his book Autobiography of a Yogi. The Autobiography has been in continuous publication since 1946 and is considered a modern spiritual classic. The book has been translated into eighteen languages and is used as a text and reference work in numerous colleges and universities.

After Yogananda graduated from Calcutta University in 1915, he took formal vows as a monk of India’s monastic Swami Order, at which time he received the name Yogananda (signifying bliss, ananda, through divine union, yoga). In 1917, Yogananda began his life's work with the founding of a "how-to-live" school for boys, where modern educational methods were combined with yoga and spirituality. In 1920, he founded the Self-Realization Fellowship (SRF) for the purpose of disseminating his teachings and for the next 32 years he lived and taught in the West.

Yogananda emphasized the underlying unity of the world's great religions, and taught universally applicable methods for attaining self-realization defined as, "The knowing, in body, mind, and soul, that we are one with the omnipresence of God; that we do not have to pray that it come to us, that we are not merely near it at all times, but that God's omnipresence is our omnipresence; that we are just as much a part of Him now as we ever will be. All we have to do is improve our knowing” (Yogananda, 1997b: p. 434).

To serious students of his teachings Yogananda introduced the meditation techniques of Kriya Yoga, part of a spiritual science originating millenniums ago in India, which had been lost in the Dark Ages and revived in modern times by his lineage of enlightened teachers. Kriya Yoga is a technique of meditation whereby the mind withdraws from sensory information and connects to the astral centers (charkas) in the central nervous system encouraging the development of spiritual consciousness. Practitioners of Kriya Yoga learn the yoga science of pranayama (conscious control of the life energy that activates and sustains life in the body) and redirect kundalini to consciously disconnect the mind and life functions and sensory perceptions that tie humans to body consciousness. According to Yogananda, pranayama thus "frees man's consciousness to commune with God."1

Central to Paramahansa Yogananda's teachings, which embody a complete philosophy and way of life, are scientific techniques of concentration and meditation that lead to the direct personal experience of Spirit. These yoga methods quiet body and mind, and make it possible to withdraw one's energy and attention from the usual turbulence of thoughts, emotions, and sensory perceptions.

\section{From Quantum to Consciousness}

According to Yogananda, "Man thinks of his body as compact, solid matter; but science now defines the body as waves of electromagnetic energy. Matter has been dissolved down to pho-

\footnotetext{
${ }^{1}$ Kundalini in yoga science refers to the powerful current of creative life energy residing in a subtle coiled passageway at the base of the spine. In ordinary waking consciousness, the body's life force flows from the brain down the spine and out through this coiled kundalini passage, enlivening the physical body and tying the astral and causal bodies and indwelling soul to the mortal form. In the elevated states of consciousness that are the goal of meditation, the kundalina energy is reversed to flow back up the spine to awaken the dormant spiritual faculties in the cerebrospinal centers (chakras).
}

tons. But what is the difference between light and consciousness; and what is the relation of consciousness and the body? The decipherment of that arcanum of cosmic being is the principal challenge confronting future generations of broadened scientific minds (Yogananda, 2004: p. 1508).

Consistent with today's quantum theorists, Yogananda explained that modern science will be able to manipulate the subtle electromagnetic constitution of man to correct most any medical condition in ways that would seem almost miraculous today. He maintained that in the future, "healing will be effected more and more by use of various types of light rays." Science has discovered that matter/energy does not exist with any certainty in definite places, but rather shows "tendencies" to exist (i.e. the "Uncertainty Principle”). Even more intriguing is the notion that the existence of an observer is fundamental to the existence of the Universe-a concept known as "The Observer Effect"-implying that the Universe is essentially a product of consciousness (i.e. the Mind of God) (Bohm, 1987). In support of Bohm's and Planck's substantive contributions to quantum physics, Yogananda stated:

Light is what we are made of - not gross physical light, but the finer spiritualized light of prana, intelligent life energy. That light is the real essence of everything. This earth is not "earth" as you see it; it is light. But you cannot perceive that until you know the underlying astral world (Yogananda, 2010: p. 11).

In ordinary consciousness man experiences three states: waking consciousness, sleeping consciousness, and dreaming consciousness. But, according to Paramahansa Yogananda and Ghose Aurobindo, humans typically do not experience the superconsciousness of the soul unless it is experienced in meditation. "As mortal man is conscious throughout his body, so the Christman is conscious throughout the universe, which he feels as his body. Thought is human consciousness in vibration. Human consciousness is delimited God-consciousness in vibration. In the process of thought man's consciousness vibrates. Through psychophysical techniques of yoga one can regain mastery of his mind, stilling the restless thought vibrations of human consciousness and entering the ecstasy of God-Consciousness" (Yogananda, 2004: p. 1581).

As a consequence of spiritual development one attains "a state wherein the fixed consciousness generated from contact with matter vanishes. Finite objects are seen as naught but imprisoned consciousness; and the formerly rigid differentiations of matter are experienced as relativities of thought, all interrelated in the preeminent, unifying Divine Intelligence from which they flow” (Yogananda, 2004: p. 224).

"I regard consciousness as fundamental," said Max Planck, the father of quantum physics. "I regard matter as derivative from consciousness. We cannot get behind consciousness. Everything that we talk about, everything that we regard as existing, postulates consciousness” (Planck, 1937).

Yogananda was not an intellectual theorist. He believed that the key to the cosmic conundrum is found not in the logical reasoning of the mind, but in the all-knowing intuition of the soul, the true self. He posited that while the theoretically wise argue the contradictions of theology, "the secretive universe will go on mysteriously spawning its paradoxes without vouchsafing an answer to intellectual queries about its inexplicable conduct.”

\section{A Vision from the East: Sri Aurobindo's Life Divine}

"To hope for a true change of human life without a change of 
human nature is an irrational and unspiritual proposition.” —Sri Aurobindo

Ghose Aurobindo (1872-1950) was an avant-garde intellectual. He sought to philosophically reconcile Western scientific rationalism with Eastern transcendental metaphysics into a holistic narrative of reality (Chaturvedi, 2002; Dalal, 2001; McGreal, 1995).

Born in Calcutta India, Aurobindo was educated at Cambridge University in Great Britain. He was profoundly influenced by Western thought: empirical pragmatism, logical rationalism and romantic idealism. Charles Darwin's evolutionary theory, French intellectual Henri Bergson's philosophy of cognitive evolution, and German philosopher G. F. W Hegel's idea of dialectical social evolution made a significant impression on his world-view. The idea of human evolution as perpetual motion became the foundation of his sociological theories, political ideology and educational thought (Bruteua, 1971, 1974; Dalal, 2001; Purani, 2001; Susai, 1993).

After graduation from Cambridge, Aurobindo returned to India. There he became politically active in the nation's struggle for independence from British imperialism. He became extraordinary political statesmen and a revolutionary firebrand in the people's struggle for national liberation. At the time, the British authorities labeled him as the most dangerous revolutionary in India. Eventually he was captured and charged for sedition, and imprisoned to solitary confinement. However he was not convicted by the British ruled court of the charges (Chaudhuri, 2002; Gandhi, 1992; Heehs, 1989; Varma, 1998).

While confined to incarceration and solitude, he experienced an overpowering spiritual transformation. He claimed to have experienced a Divine presence "as all beings and all that is". After this experience, he now visualized all of reality as being unified. Thereafter Aurobindo immersed himself in the study of Hindu philosophy. The Eastern notion of metaphysical monism, a non-dualistic Absolutely Reality that exists behind empirical world of physical appearance, was infused throughout his thought (Bruteua, 1974; Chaturvedi, 2002; Feys, 1977; Vrekhem, 1998).

Aurobindo viewed himself as a spiritual revolutionary advocating a new politics of consciousness. Because of humankind's unique evolution as a species, we are collective custodians and guardians of the world. He set out to see through the empirical world and realize the ultimate unification of being behind this outward appearance. He stated that it is easier to experience the finite being of the real world but it is more difficult to see the infinite unification of being. From this realization; Aurobindo began writing volumes of scholarly works on social issues and while philosophically developing a system of metaphysical idealism-Ultimacy. In time, his fellow countrymen affectionately conferred upon him the honorific title of "Sri" Aurobindo (The term "Sri" is from the Sanskrit language, a Hindu honorific title meaning-“Master”) (Gandhi, 1992; Heehs, 1999: Price, 1977; Singh, 1989).

Aurobindo became convinced that Hindu spirituality, meditative yoga, would augment his political vision as reflective social action. Political thought, social work, and the quest for self-realization are interconnected human endeavors. He termed this notion as Integral Yoga. Integral Yoga seeks to change of our inner self and outer life as a manifestation of a higher level of consciousness (Aurobindo, 1971, 1985a, 1985b, 1990, 1998a; Kluback, 2003).
In many respects, his yogic method is a reaction to unbridled eastern mysticism and western hyper rationalism. It is a synthesis of Western psychology, which focuses on the outer personality and social behavior, with the spiritual psychology of the East, which focuses on the inner person and consciousness. Integral yoga is not a specific physical or psychological procedure but it is to consciously surrender to universal evolutionary energy. This numinous evolutionary energy causes increasing levels of personal involution, spiritual consciousness, which is necessary for future social progress. Integral Yoga causes a transformation of the psyche-world within observable as a radical shift in the social life-world without. An understanding of his theory of integral yoga is essential to comprehending and futuristic idealism of Ultimacy ${ }^{2}$ (Aurobindo, 1993; 1998b; Dalal, 2003; Feys, 1977; Overzee, 1992; Rishabachand, 1993; Susai, 1993; Vrekehm, 1998; Wygant, 2001).

Aurobindo states (Chaturvedi, 2002):

The way of yoga must be a living thing not a mental [psychological] principal or a set [physical] method to be struck to against all necessary variations... A spiritual evolution, an evolution of consciousness in matter is a contrast developing self-formation till the form can reveal the indwelling spirit.. the central significant motive of the terrestrial existence (pp. 54-55).

In 1947, after the emancipation of India, Aurobindo devoted himself entirely, along with his soul mate and social comrade the French mystic Mirra Alfassa (referred to as The Mother, a Hindu honorific title) to liberate the whole of humanity socially and spiritually by advancing conscious transformation and advancing the construction of a new social reality of global unity (Aurobindo, 1998a; Bruteau, 1974; Dalal, 2001).

Aurobindo's philosophical magnum opus is The life divine (1974a) while The future evolution of man (1974b) is his most ambitious sociological analysis. These works are a theoretical synthesis of Western evolutionary thought and Neo-Hinduism. They provide a comprehensive narrative of the relationship between psyche involution and social evolution (Bruteau, 1974; McGreal, 1995; Susai, 1993; Zaehner, 1971).

\section{Transcending the Levels of Consciousness}

Consistent with Eastern philosophy, Aurobindo asserted that planetary evolution has resulted in distinctive earthly realms of existence. Each earthly realm has a discernable evolutionary direction and elevated appearance of the psyche. He identifies four distinct yet unified earthly realms with a corresponding reality: Material realm (physical reality), life realm (biological reality), intellectual realm (psyche-social reality), and metaphysical realm (higher consciousness-spiritual reality) (Aurobindo, 1998b; Bruteau, 1974; Combs, 1996; Vrekhem, 1998)

He describes how matter evolved into life resulting ultimately in the emergence of the human specie with an elevated level of consciousness. With the advent of the human species a more complex process of evolution was set in motion. Because

\footnotetext{
${ }^{2}$ Aurobindo explained that an effective motive for social action cannot emerge without a corresponding "Ultimate Ideas of Purpose." To educate towards the construction of a future social order that is a greater state of existence than our present social order without an idea of ultimate meaning is like putting the cart before the horse. Ideas of ultimacy provide learners with a meaningful mental model of the larger Self that can result in collective social action. Holistic education is the proper theoretical forum from which to promote idealism of ultimate meaning (Forbes, 2003: pp. 18-22).
} 
evolution is in perpetual motion, it follows that the human specie cannot be the end point of previous evolutionary movement but is a unique transitional stage (Aurobindo, 1974a, 1974b, 1998a, 1998b; Combs, 1996; Dalal, 2001, 2003; McGreal, 1995; Vrekehm, 1998).

Aurobindo theorizes that there has evolved seven evolutionary states of mind (psyche) with distinctive degree of consciousness more elevated than the previous level: Physical mind is the most basic state of the brain producing elemental consciousness. Vital mind is the state of life mind with a level of consciousness associated with meta-cognition and affective modes of thinking. Higher mind (a transitional state) is the state of mind resulting in the first level of elevated consciousness. It is a transitional state between base biological mind and that of reflective knowing (higher consciousness). Illuminated mind is a more complex level of consciousness that has characteristics of intuitive knowing and producing hyper-visionary thinking. Intuitive mind represents a distinct state of mind and level of consciousness empowered by an astute awareness of Absolute Reality. This degree of consciousness is found manifested in extraordinary persons endowed with innovative insights and a novel sense of relevance regarding the future human evolution. Over mind (a transitional state) is a state of mind characterized by a transcendental level of consciousness. It is the cognitive ability for integrative thinking, unitary knowing and mystical insight.

Accordingly, in our age a few individuals have emerged revealing this level of evolution. They are the pathfinders for future human evolution and eventual global-unity. Supramind (i.e., Supermind) is a future state of mind, the highest state of psyche, and is a total transformation of the human specie into a new breed of life and mind. While all the previous levels of minds are supported solely by physical and psyche realms of realities. Supramind is grounded upon Absolute Reality, the Life Divine. Supramind is the Life Divine fully manifested on Earth. He defines the Supramind as the human psyche bathed in divine energy that totally transforms consciousness and empowers individuals to reconstruct human relations into a social solidarity constructing a collective new global unity (Aurobindo, 1974a, 1974b, 1985b, 1991, 1998a, 1998c; Bruteau, 1971, 1974; Combs, 1996; McGreal, 1995; Mukherjee, 1990; Satprem, 1984, 1985; Vrekehm, 1998).

He writes (1974a):

The animal is the living laboratory of the evolutionary urge, illuminating and change must take up and re-create the whole being, mind, life, and body: it must not be only an inner experience of the divinity but a remodeling of both the inner and outer existence by its power; it must take form not only in the life of the individual but as a collective life of Gnostic beings [Supermen] (p. 68) (Table 1).

Aurobindo declares that the notion of Life Divine is not a theory of an other worldly reality, strictly an esoteric idealism. Life Divine is a tangible energy infusing ever-higher expressions of consciousness bringing about greater evolutionary unfolding through humankind into the world. Supramind results in individuals becoming fully aware of their uniqueness as well as their psyche and social unification with others without perceived contradictions between the two. The process of involution of Life Divine on planet Earth is resulting in the birth of a new species, a "Gnostic being" or a being of knowledge, endowed with the capacity to steer future social evolution toward a state of global-unity (Aurobindo, 1985b, 1991, 1998a, 1998b, 1998c; Mukherjee, 1990; Satprem, 1984; Vrekehm, 1998).

Thus, for Aurobindo, humankind is currently in movement toward a new stage of evolution is resulting in an increasing number of individuals' experiencing a deeper degree of consciousness desiring a unifying global evolution. Accordingly, our age is witnessing the advent of a new and novel social life-world being born that will become vastly more advanced than our stage of existence. The involution of divine spirit into individual's psyche development is driving societies toward increasingly advanced levels of collective consciousness. Societies will continue to evolve toward greater interaction and thus converge amongst themselves constructing higher degrees of collective consciousnesses and greater social globalization (1974b).

The appearance of mind and body on earth makes a critical step, a deceive change in the course of evolution. There is an evolution of the consciousness behind the evolution of the species and this spiritual evolution must end in a realization, individual and collective, on the Earth. Man is a transitional being who has seen that there can be a higher status of consciousness than his own. ...the being has become awake and aware of himself; there has been manifest in mind its will to develop, to grow in knowledge, to deepen the inner and widen the outer existence to increase the capacities of nature. Man has seen that there can be higher states of existence than his own. For truth and knowledge is an idle gleam if knowledge bring not power to change the world (p. 51).

\section{Global Education}

The convergence of humanity into an intensified global-unity will not result in an impersonal society of estranged individuals but will actually unite individuals. The transformation of consciousness will result in persons becoming free of self-interested ego driven individualism through becoming reflectively aware of their own psyche development within the context of others experiencing the same process. He theorized that humankind has entered a new age of accelerated personal involution and social evolution on a global scale. The consequence is that the transformation of an individual's self-consciousness is perpetuated through the intensification of social interaction with others who are experiencing the same evolutionary pro0 gression. A harmonized collectivity of consciousness, the Supramind creating a New Human Specie, is emerging. The immediate future of humankind can be understood as the collec-

Table 1.

Aurobindoian Vison of Psyche/Social Evolution.

Absolute Reality-Supramind

(Evolution of Collective Global Consciousness)

\begin{tabular}{|c|c|}
\hline \multicolumn{2}{|c|}{ Over-Mind (transitional evolutionary state) } \\
\hline $\begin{array}{l}\text { Metaphysical Realm } \\
\text { (Higher consciousness/spiritual) }\end{array}$ & Intuitive Mind \\
\hline $\begin{array}{l}\text { Intellectual Realm } \\
\text { (Psyche-social) }\end{array}$ & Illuminated Mind \\
\hline \multicolumn{2}{|c|}{ Higher Mind (transitional evolutionary state) } \\
\hline $\begin{array}{l}\text { Life Realm } \\
\text { (Biological) }\end{array}$ & Vital Mind \\
\hline $\begin{array}{l}\text { Material Realm } \\
\text { (Physical) }\end{array}$ & Physical Mind \\
\hline
\end{tabular}


tive transformation of humankind occurring on the social and individual levels (1974b, 1985a, 1991).

Aurobindo doggedly believed that human progress and global convergence is occurring despite persistent international socioeconomic strife and political conflict. These set backs are only evolutionary birth pangs of a coming new age of global cooperation and planetary consciousness (1991, 1998a, 1998b). The "Ultimate" future of human evolution is not merely an individual affair but a communal one. The community exists by the individual, not vice versa and a perfected community can exit only if the members are perfected. The community exists to serve the individual but is the duty of the individual to sacrifice themselves for the sake of the community. Consequently he visualizes a future state of existence that will embrace us into a new collective social reality of ultimacy regarding global-consciousness (Aurobindo, 1974; Bruteau, 1971).

\section{Relevance of Yogananda and Aurobindo's Thought as Core Principles for Western Education}

"The most important question for curriculum is 'How can school become more like life?’”

-P. Yogananda

"The Divine Truth is greater than any religion or creed or scripture or idea or philosophy.”

—Sri Aurobindo

The great American horticulturalist Luther Burbank once wrote that the "idea of right education is plain commonsense, free from all mysticism and non-practicality". In addition to their close friendship, Yogananda and Burbank shared similar educational philosophies. Burbank endorsed spiritual training for educators claiming that:

"It is ideal for training and harmonizing man's physical, mental, and spiritual natures ..."

Burbank further suggested that Americans establish,

"How-to-Live" schools throughout the world, wherein education will not confine itself to intellectual development alone, but also training of the body, will, and feelings. Through a system of physical, mental, and spiritual unfoldment by simple and scientific methods of concentration and meditation, most of the complex problems of life may be solved" (Yogananda, 1997a: p. 413).

Yogananda's school for boys in Dihika, West Bengal combined modern educational techniques with yoga training and spiritual ideals. This school would later become Yogoda Satsanga Society of India, the Indian branch of Yogananda's American organization.

Students who are taught that humans are merely "higher animals," according to Yogananda may be more prone to developing atheistic values and avoid attempts to investigate spiritual practices. Emerson observed, "That only which we have within, can we see without. If we meet no gods, it is because we harbor none". One who imagines their animal nature to be the only reality, may be more likely to be cut off from spiritual aspirations.

According to Eastern philosophy, educational systems that do not present Spirit as the central fact of human existence offer avidya, or false knowledge (Yogananda, 1997a: p. 207). Among the Eastern philosophical tenets, the ideal of education includes moral and spiritual values within the formal curriculum, without whose appreciation no student can approach feelings of great happiness, especially of a spiritual nature. According to Yogananda (1997a: p. 303), "true education is not pumped and crammed in from outward sources, but aids in bringing to the surface the infinite hoard of wisdom within.”

Yogananda's philosophy is an attempt to rationally and systematically re-vision the art and science of teaching and learning as consciousness within Eastern perspectives of metaphysics synthesized with science. Both men's vision of constructivist consciousness is remarkable in scope. The suggestion here is that a synthesis of Yogananda's and Aurobindo's thought provides common core principles to understand the "what is" the process of education:

- The expansion of consciousness, on both the individual and collective level, has now empowered humankind to discover and acquire deeper knowledge.

- The next stage of social evolution demands cooperative action and solidarity on the part of humankind, at all levels. What must proceed through collaboration are knowledge construction and the consciousness for reconstructing society and advancing knowledge then could be accomplished on just an individual segregated means.

Both individuals argue that in the past humankind has sought perfecting its environment through social institutions. But it is only by the involution of our individual consciousness, shared in collaboration as collective consciousness and mind, that genuine social transformation can be attained. Education is in the midst of this transformative process. The challenge for all educators today is to more fully participate in this transformation by fostering collective academic collaboration and integrative intellectual cooperation (Yogananda, 1997, 2001, 2004).

Accepting Yogananda and Aurodindo’s postulation, educating to a positive future inherently requires academic collaboration. Humankind must become educated of the possibility of its own conscious transformation and social evolution. We in higher education are its agents and models of such a level of collaboration. In doing so, we can potentially overcome the barriers that fragment humankind today with the potential of stalling future evolutionary movement. We must educate toward the future with a new vision that we are responsible for rational political, social and economic through deeply reflecting on the process of collaboration in academia (Bruteau, 1974; Cowell, 2001).

For us, this statement summarizes nicely how we perceive education today. It is for us the cooperative sharing of our minds and thoughts resulting in higher levels of knowing and knowledge. We do seek to be objective and pragmatic yet being subjectively aware of others, being rational yet emotive as we become conscious that there is not one best way to address problems as well as espousing our own thoughts. Thus the educative process consists of becoming aware of our need for others thoughts, insights, and the act of integrative minds regardless of the problem or issue under critical assessment and learning.

The suggestion here is that a synthesis of Yogananda and Aurobindo's thought provides us with a set of common core values for a Western educators: 1) humankind as species is still in evolutionary movement and that our current state of existence is only a transitory one; 2) current evolutionary movement is progressing on a global scale toward a point of human unity; 3) consciousness is the apex of past evolutionary phenomenon and focal point of future evolutionary expansion; 4) the expansion of consciousness, on both the individual and 
collective level, has now empower humankind to direct evolutionary movement; 5) for the next evolutionary stage to be realized demands global solidarity on the part of humankind from the integrative association of transformed individuals who are consciously constructing a new global reality; and 6) the far distant future is visualized as holding positive promises that will "Ultimately" transform humankind and reality into a new specie of higher spiritual essence.

Both intellectuals visualized that for the first time evolution, a species has emerged that can consciously participate in its own evolution. This phenomenon presents an unprecedented opportunity for educators. Their thought provides global educators with Eastern and Western perspectives of social evolution, conscious transformation, and futurism resulting in a logical foundation to formulate a notion of global unity and diversity.

\section{REFERENCES}

Aurobindo, S. (R. A. McDermott Ed.) (1971). The mind of light. New York: Dutton and Co.

Aurobindo, S. (1974a). The life divine. Pondicherry: Sri Aurobindo Ashram Press.

Aurobindo, S. (1974b). The future evolution of man: The divine life upon earth. Wheaton, IL: Quest Books-The Theosophical Publishing House.

Aurobindo, S. (1985a). Social evolution towards the ideal of human unity. Pondicherry, India: Sri Aurobindo Ashram Press.

Aurobindo, S. (1985b). Future poetry. Twin Lakes, WI: Lotus Press.

Aurobindo, S. (1990). A synthesis of yoga. Twin Lakes, WI: Lotus Press.

Aurobindo, S. (1991). The superman (6th ed.). Pondicherry: Sri Aurobindo Ashram Press.

Aurobindo, S. (1993). Integral yoga: Sri Aurobindo's teaching and method of practice. Twin Lakes, WI: Lotus Press.

Aurobindo, S. (1995) A new education for a new consciousness (2nd ed.). Pondicherry: Sri Aurobindo Ashram Press.

Aurobindo, S (1998a). The ideal of human unity. Pondicherry: Sri Aurobindo Ashram Press.

Aurobindo, S. (1998b). Glossary of terms in Sri Aurobindo writings (2nd ed.). Pondicherry: Sri Aurobindo Ashram Press.

Aurobindo, S. (1998c). The human cycle: The psychology of social development. Twin Lakes, WI: Lotus Press.

Aurobindo, S. (2000). Sri Aurobindo and the mother on education. Twin Lakes, WI: Lotus Press.

Bertrand, Y. (2003). Contemporary theories \& practices in education. Madison, WI: Atwood Publishing.

Bohm, D. (1987). Science, order, and creativity. New York: Bantam.

Chaturvedi, A. N. (2002). Sri Aurobindo: The spiritual revolutionary. New Delhi: Rupa \& Co.

Combs, A. (1996). The radiance of being: Complexity, chaos, and the evolution of consciousness. St. Paul, MN: Paragon Books.

Dalal, A. S. (2001). A greater psychology: An introduction to the thought of Sri Aurobindo. New York: Jeremy P. Tarcher.

Dalal, A. S. (2003). Our many selves: Practical yogic psychology. Twin Lakes, WI: Lotus Press.

Dowsett, N. C. (1977). Psychology for future education. Pondicherry: Sri Aurobindo Society.

Dowsett, N. C., \& Jayawal, S. R. (1976). Education for the future. Pondicherry: Sri Aurobindo Society.

Feys, J. (1977). The yogi and the mystic: Sri Aurobindo and Aurobindo de Chardin. Calcutta: Firma KLM Ltd.

Forbes, S. H. (2003). Holistic education: An analysis of its ideas and nature. Brandon, VT: Foundations for Educational Renewal Publisher.

Gandhi, K. (1992). Social philosophy of Sri Aurobindo and the new age. (2nd ed.). Pondicherry: Sri Aurobindo Ashram Publication Department.

Glazer, S. (1994). The heart of learning: Spirituality in education. New York: Jeremy P. Tarcher.

Hamilton, C. (2004). The future of god, evolution and enlightenment for the 21st century. The Journal of Yoga, 3 .

Heehs, P. (1989). Sri Aurobindo: A brief biography. Oxford: Oxford University Press.

Heehs, P. (Ed.) (1999). The essential writings of Sri Aurobindo. Oxford: Oxford University Press.

Kessler, R. (2000). The soul of education: Helping students find connection, compassion, and character at school. Alexandria, VA: Association for Supervision and Curriculum Development.

Kluback, W. (M. Kinkenthal Ed.) (2003). Sri Aurobindo Ghose: The dweller in the lands of silence. St. Paul, MN: Paragon House.

Marshak, D. (1997). The common vision: Parenting and educating for wholeness. New York: Peter Lang Publishing.

McDermott, R. (Ed.) (1987). The essential Aurobindo. New York: Lindsfarne Books.

McGreal, I. P. (Ed.) (1995). Great thinkers of the eastern world. New York: Harper Collins.

Miller, J. P., \& Nakagawa, Y. (2002). Nurturing our wholeness: Perspective on spirituality in education. Brandon, VT: Foundation for Educational Renewal.

Moffett, J. (1994). Spiritual awakening through education. San Francisco: Jossey-Bass.

Monor, R. (1998). Sri Aurobindo: The perfect and the good. Calcutta: Firma KLM.

Mukherjee, J. K. (1990). From man human to man divine: Sri Aurobindo's vision of the evolutionary destiny of man. Pondicherry: Sri Aurobindo International Center for Education.

Overzee, A. H. (1992). The body divine: The symbol of the body in the works of Aurobindo, Teilhard de Chardin and Rāmānuja. Cambridge: Cambridge University Press.

Ozman, H. A., \& Craver, S. M. (1999). Philosophical foundations of education (6th ed.). Upper Saddle, NJ: Prentice Hall, Inc.

Paine, J (1998). Father India: How encounters with an ancient culture transformed the modern west. New York: Harper Collins.

Palmer, P. (1993). To know as we are known. San Francisco: Harper Collins.

Purani, A. B. (2001). The life of Sri Aurobindo (4th ed.). Pondicherry, India: Sri Aurobindo Ashram Press.

Rishabachand, (1993). The integral yoga of Sri Aurobindo. Twin Lakes, WI: Lotus Press.

Rizvi, F., \& Lingard, B. (Eds.) (2000) Symposium on globalization and education. Educational Theory, 50.

Satprem. (1984). Sri Aurobindo or the adventure of consciousness (Trans. Luc Venet). New York: The Institute for Evolutionary Research.

Satprem. (1985). On the way to supermanhood (Trans. Luc Venet). New York: The Institute for Evolutionary Research.

Sinetar, M. (2000). Spiritual intelligence: What we can learn from the early awakening child. Maryknoll, NY: Orbis Press.

Singh, K. (1989). The prophet of Indian nationalism. New Delhi: Bharatiya Vidya Bhavan.

Susai, A. (1993). The neo-Hindu concept of man: In the light of Sri Aurobindo's evolutionary vision. New Delhi: Intercultural Publications.

Varma, V. P. (1998). The political philosophy of Sri Aurobindo. New Delhi: Motilal Banarsidass.

Viotti, P. R., \& Viotti, M. V. (1998). International relations theory: Realism, pluralism, globalization and beyond. Saddle River, NJ: Prentice-Hall.

Vrekehm, G. V. (1998). Beyond the human species: The life and work of Sri Aurobindo and the mother. St. Paul, MN: Paragon House.

Wygant Jr., W. E. (2001). Of one blood: A study of the parallels in Christianity and Sri Aurobindo's integral philosophy. Haverford, PA: Buy Books

Yogananda, P. (1997a). Autobiography of a yogi. Los Angeles, CA: Self-Realization Fellowship.

Yogananda, P. (1997c). Journey to self-realization. Los Angeles, CA: Self-Realization Fellowship.

Yogananda, P. (2001). Man's eternal quest. Los Angeles, CA: SelfRealization Fellowship.

Yogananda, P. (2004). The Second Coming of Christ. Los Angeles, CA: Self-Realization Fellowship.

Yogananda, P. (2010). Connecting your life with the astral world. SelfRealization Magazine, 81, Los Angeles, CA: Self-Realization Fellowship. 